\title{
Hepatotoxicity and Histological Evaluation of Aqueous and Methanolic Leaf Extracts of Thaumatococcus Daniellii and Alchornea Cordifolia in Wistar Rat Models
}

\author{
Okafor, I. J. ${ }^{1}$, Nweke, E. O. ${ }^{1}$ \& Ewa, O. ${ }^{2}$ \\ ${ }^{1}$ Department of Human Anatomy, Chukwuemeka Odumegwu Ojukwu University Uli, Nigeria \\ ${ }^{2}$ Department of Medical Biochemistry, Gregory University Uturu, Nigeria \\ Correspondence: Ewa Ogbonnaya, Department of Medical Biochemistry, Gregory University Uturu, Nigeria.
}

Received: December 6, 2018; Accepted: December 19, 2018; Published: January 4, 2019

\begin{abstract}
This study was carried out to ascertain the hepatotoxic potential of T.daniellii (T.d) and A. cordifolia (A.c). Investigations were conducted using standard methods. Oral administration of $200 \mathrm{mg} / \mathrm{kg}$ aqueous leaf extracts of T.daniellii caused a non-significant increase in the activity of ALT (5.43 $\pm 0.60 \mathrm{IU} / \mathrm{L})$, AST $(16.93 \pm 0.26 \mathrm{IU} / \mathrm{L})$ and ALP (160.70 $\pm 1.04 \mathrm{IU} / \mathrm{L})$ compared to the values recorded on the normal control (group I) ALT (3.84 $\pm 0.16 \mathrm{IU} / \mathrm{L}$ ), AST $(14.19 \pm 0.52 \mathrm{IU} / \mathrm{L})$ and ALP $(157.26 \pm 0.64 \mathrm{IU} / \mathrm{L})$. Group III administered with $200 \mathrm{mg} / \mathrm{kg}$ methanolic leaf extract of $T$. daniellii manifested a significant elevation in the activity of ALT (13.15 $\pm 0.89 \mathrm{IU} / \mathrm{L})$, AST $(22.84 \pm 0.38 \mathrm{IU} / \mathrm{L})$ and ALP $(170.40 \pm 0.44 \mathrm{IU} / \mathrm{L})$ compared to the normal control. Similarly, groups IV and V which were orally administered with $200 \mathrm{mg} / \mathrm{kg}$ aqueous and methanolic leaf extracts of $A$. cordifolia showed significant increase in the activity of ALT $(6.32 \pm 0.33 \mathrm{U} / \mathrm{L})$, AST $(17.70 \pm 0.030 \mathrm{U} / \mathrm{L})$ and ALP $(161.13 \pm 0.09 \mathrm{U} / \mathrm{L})$ and ALT ( $7.55 \pm 0.59 \mathrm{U} / \mathrm{L})$, AST $(19.35 \pm 0.26 \mathrm{U} / \mathrm{L})$ and ALP $(165.38 \pm 0.35 \mathrm{U} / \mathrm{L})$ respectively compared to the values recorded on the control (group I). In conclusion, drug development protocols involving $T$. daniellii leaf should preferably use water as an ideal solvent. On the other hand, the hepatotoxicity associated with both aqueous and methanolic extracts of $A$. cordifolia could imply the presence of hepatotoxins in the leaf of the said plant.
\end{abstract}

Keywords: Thaumatococcus daniellii, Alchornea cordifolia, hepatotoxin, Enzyme

\section{Introducton}

The liver which is the largest organ of the body is strategically located between the gastrointestinal tract and general circulation (Chiang, 2014). It possesses a domed upper surface which relates wholly to the diaphragm, while its visceral surface which carries the gall bladder rests upon the stomach, upper duodenum, hepatic flexure of the colon, right kidney and suprarenal gland (Chiang, 2014).

The liver being a metabolically active organ plays a central role in the metabolism of xenobiotics and distribution of nutrients. In addition, this very important organ uses carbohydrates to synthesize cholesterol and fatty acids, stores glucose inform of glycogen and free fatty acids as triglycerides (TG). The liver maintains blood glucose levels during fasting by processes known as gluconeogenesis and glycogenolysis. It converts excess fatty acids to ketone bodies, a process which ensures energy generation and supply to the brain and muscle during starvation (Chiang, 2014).

Hepatotoxicity is a concept which defines any form of damage to the liver brought about by a chemical agent also known as hepatotoxins and may include drugs used for therapeutic purposes either when used excessively or even within therapeutic ranges (Aashi et al., 2011). Very often damage to the liver has resulted to death.

Thaumatococcus Daniellii (Benth), also known as the sweet prayers plant or katemfe, grows undergrowth of forest trees throughout the hot and humid tropical rain forest and coastal zones of West Africa (Mansfeld, 1986). The aril of $T$. daniellii, contains thaumatin an intensely sweet, non-toxic and heat stable protein which is extracted and used as sweetener or taste modifier in beverages, chewing gums and pet foods. Medicinally, the leaf sap of $T$. daniellii is used as an anti-dote for venoms, stings and bites, while the leaf has excelled as a sedative and has been used successfully in the treatment of mental illness (Onwueme et al., 1979).

Alchornea cordifolia, also known as Christmas Bush is a shrubby tree of the family Acalypholdeae. Predominantly found in marshy areas of the coastal regions of West Africa. The leaves of the plant are used in the treatment of 
pain, rheumatism, arthritis, pile, toothache and inflammation (Osadebe \& Okoye, 2003). It has been shown to possess antibacterial, antifungal and anti-spasmolytic properties (Agbor et al., 2004; Tona et al., 2000). Although these reports abound on the medicinal values of these plants, detailed information on their hepatotoxic effects is yet to emerge. Therefore, it is imperative to evaluate the hepatotoxicity of $T$. daniellii and A. cordifolia leaves in order to consolidate or discard the recorded benefits associated with its use as medication and feed for human and livestock respectively.

\section{Materials and Methods}

\subsection{Collection of Processing of Plant Material}

Mature leaves of $T$. daniellii and A. cordifolia used for the study were collected from a farmland within Uturu community of IsiukwuatoLocal Government Area of Abia State, Nigeria. The leaves were identified at the herbarium unit of the Department of Forestry, Micheal Okpara University of Agriculture Umudike, Abia State Nigeria. Leaves from each plant were thoroughly washed with clean water, spread in the laboratory to dry at room temperature before being ground to powder using electric blender. The powdered plant materials were sieved with a suitable wire mesh to obtain a fine powder which was stored in an appropriately labeled container with a screw cap.

\subsection{Extraction of Plant Materials}

Fifty gram $(50 \mathrm{~g})$ each of the powdered plant samples were soaked separately in $1000 \mathrm{ml}$ methanol and water and macerated at room temperature for a period of $72 \mathrm{~h}$ and agitation thrice daily. The mixture was strained, the marc (the damp solid material) was pressed, and the combined liquids were clarified by filtration using cheesecloth and Whatman No. 1 filter paper. The filtrate were extracted using soxhlet apparatus for 5-6h and concentrated under pressure to dryness in rotary evaporator at $25-30^{\circ} \mathrm{C}$ (Phrompittayarat et al., 2008). The extracts were stored in refrigerator and maintained at $5-10^{\circ} \mathrm{C}$.

\subsection{Animal}

Twenty five (25) adult male wistar rats (116-122 g) were purchased from the Animal House of the Department of Pharmacology University of Nigeria Nsukka. They were housed in metal cages for two weeks to acclimatize. Rats were fed with rat chow and were allowed access to water ad-libitum.

\subsection{Median Lethal Dose 50\% Test (LD50)}

Acute toxicity test was carried out separately on $T$. daniellii and $A$. cordifolia leaf samples. Three groups of three rats each were administered $10 \mathrm{mg}, 100 \mathrm{mg}$, and $1000 \mathrm{mg} / \mathrm{kg}$ of sample material orally. The rats were observed for $24 \mathrm{hrs}$. In the absence of mortality in any of the test groups, another three groups of one rat each were administered with 1600,2900 and $5000 \mathrm{mg} / \mathrm{kg}$ of extracts respectively. The animals were observed for $48 \mathrm{hrs}$ (Lorke, 1983).

\subsection{Experimental Design}

Twenty five adult male wistar rats were grouped into five groups of five rats each and were treated for a period of three weeks as follows:

Group I (normal control) - 2ml $/ \mathrm{kg}$ distilled water (p.o)

Group II - 200mg/kg aqueous extract of T.d (p.o)

Group III - 200mg/kg methanolic extract of T.d (p.o)

Group IV - 200mg/kg aqueous extract A.c (p.o)

GroupV - 200mg/kg methanolic extract A.c (p.o)

\subsection{Evaluation of Liver Enzyme Activity}

Blood samples collected from the animals were centrifuged and resulting sera stored in refrigerator at $-20{ }^{\circ} \mathrm{C}$. Enzyme activities were determined with the aid of commercial enzyme kits manufactured by the Biorex fars company using automated analyzer device.

\section{Histopathology}

Liver tissues generated from the various experimental groups were harvested and preserved in $10 \%$ formalin. Sectioning of tissues was conducted using microtome. Graded alcohol was used for tissue dehydration prior to embedment with paraffin section. Tissue staining was done using hematoxylin and eosin (H\&E). Specimens were studied under light microscope (Akharaiyi et al., 2015). 


\section{Statistical Analysis}

Statistical analysis was performed using IBM Statistical Package for the Social Sciences statistical package (SPSS) V 23.0. Data were expressed as means \pm SEM of three replicates.

\section{Result}

Table 1. Activity of Liver enzymes in aqueous and methanolic leaves extracts of T. daniellii and A. cordifolia

\begin{tabular}{llll}
\hline Enzyme Activities & & & \\
\hline GROUPING & ALT(IU/L) & AST(IU/L) & ALP(IU/L) \\
Group I (Normal CTRL) & $3.84 \pm 0.16$ & $14.19 \pm 0.52$ & $157.26 \pm 0.52$ \\
GroupII(200mg/kg aq T.d) & $5.43 \pm 0.60$ & $16.93 \pm 0.26$ & $160.70 \pm 1.04$ \\
GroupIII(200mg/kg met T.d) & $13.15 \pm 0.89$ & $22.84 \pm 0.38$ & $170.40 \pm 0.45$ \\
GroupIV(200mg/kg aq A.c) & $6.32 \pm 0.33$ & $17.70 \pm 0.30$ & $161.13 \pm 0.09$ \\
GroupV(200mg/kg met A.c) & $7.55 \pm 0.59$ & $19.35 \pm 0.26$ & $165.38 \pm 0.35$ \\
\hline \multicolumn{4}{l}{ Values are expressed as mean \pm standard error of mean from three determinations }
\end{tabular}

Values are expressed as mean \pm standard error of mean from three determinations

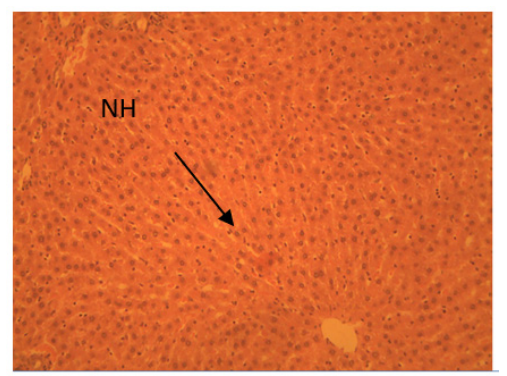

GI (Normal control)

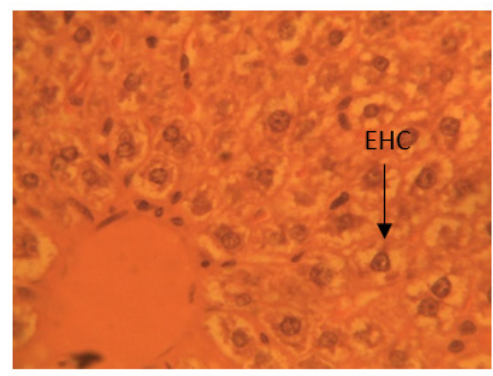

GIV (200mg/kg aq. A.c extract)

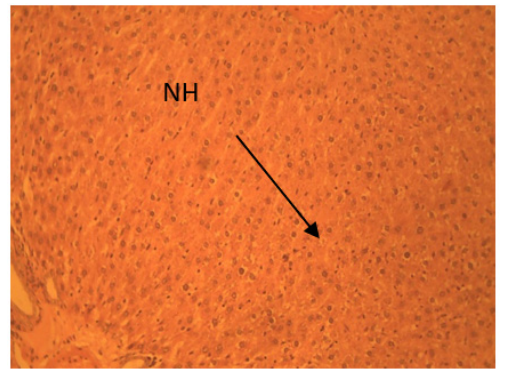

GII (200mg/kg aq. T.d extract)

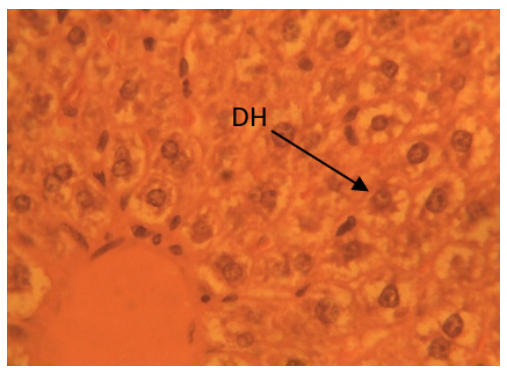

GV $(200 \mathrm{mg} / \mathrm{kg}$ met. A.c extract)

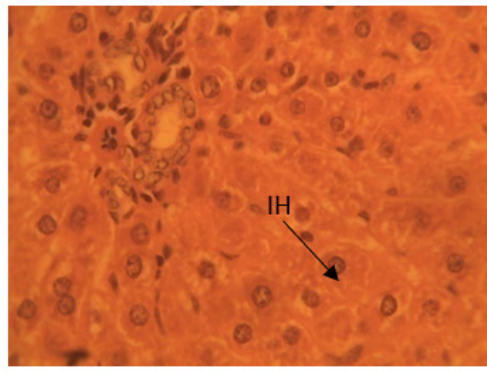

GIII (200mg/kg met. T.d extract)

Figure 1. Histopathological Findings

Table 1 shows the activity of liver enzymes following oral administration of aqueous and methanolic extracts of T. daniellii and A. cordifolia. Group I (normal control) which was orally administered with $2 \mathrm{ml} / \mathrm{kg}$ distilled water presented minimal activity of serum hepatomarkers ALT (3.84 \pm 0.16 ), AST (14.19 \pm 0.52 ) and ALP (157.26 \pm 0.64$)$.Group II administered with $200 \mathrm{mg} / \mathrm{kg}$ aqueous leaf extract of $T$. danielli manifested increased levels of serum hepatomarkers ALT (5.43 \pm 0.06$)$, AST (16.93 \pm 0.26$)$ and ALP $(160.70 \pm 1.04)$ although not significantly different from the value recorded on group I. This result is consistent with the finding of Shalom et al (2018) which states that $T$. daniellii leaf extract is hepatoprotective. However, group III presented a significant increase in the activity of ALT (13.15 \pm 0.89$)$, AST (22.84 \pm 0.38$)$ and ALP (170.40 \pm 0.45$)$ compared to the normal control (group I). Similar observation was made on groups IV and V administered orally with $200 \mathrm{mg} / \mathrm{kg}$ aqueous and methanolic leaf extracts A. cordifolia respectively as follow; ALT (6.32 \pm 0.33$)$, AST (17.70 \pm 0.030 and ALP (161.13 \pm 0.09$)$ and ALT (7.55 \pm 0.59$)$, AST (19.35 \pm 0.26$)$ and ALP (165.38 \pm 0.35$)$ respectively. This finding contradicts the work of Olaleye et al (2006) which opines that leaf extract of A. cordifolia is hepatoprotective. This does not in any way invalidates the outcome of this research as the liver has limited ability to tolerate insults resulting from different toxins in the body and thus, hepatotoxic impact of $A$. cordifolia may be dose dependent. This is evident by the fact that certain medicinal agents when taken in over dose may injure the organ (Ostapowicz et al., 2002). The Activities of livers enzymes reported in this study were supported with aid of histological reports. 
Figure 1 shows the photomicrograph of liver tissue of rats administered distilled water (group I) indicating normal arrangement of hepatocytes $(\mathrm{NH})$ with proper alignment of the central vein. Similar observation was made on group II administered with $200 \mathrm{mg} / \mathrm{kg}$ aqueous extract of $T$. daniellii. However, Group III administered with $200 \mathrm{mg} / \mathrm{kg}$ methanolic extract of $T$. daniellii presented inflamed hepatocytes (IH) with enlargement of central vein. Group IV administered with $200 \mathrm{mg} / \mathrm{kg}$ aqueous extract of A. cordifolia manifested an enlarged hepatic cells (EHC) with an abnormal proliferations around the central vein. Photomicrograph generated on Group V presented degenerating hepatocytes (DH) with sunken appearance.

\section{Conclusion}

Research efforts have established the therapeutic efficacy of $T$. daniellii and A. cordifolia in the management of diverse human diseases. Unfortunately, not much is known about their safety margin. This if allowed to linger may affect their proper and effective usage in health care delivery. Therefore, effort should be intensified through research to organize dose oriented investigations to hurriedly establish the safety margin for these two important medicinal plants to maximize use and associated benefits.

\section{Refernces}

Aashish, P., Tarun, S., \& Pallavi, B. (2011). Drug-Induced Hepatotoxicity: A Review. Journal of Applied Pharmaceutical Science, 2(5), 233-243.

Agbor, G. A., Leopold, T., \& Jeanne, N. Y. (2004). Anti-diarrheal activity of Alchornea cordifolia leaf extract. Phytotherapy Research, 18(11), 873-876.

Akharaiyi, F. C., Boboye, B., \& Akpambang, V. O. (2015). Antibacterial and biochemical effects of ethanol leaf extract of Senna hirsuta mill using animal model-mice. J. Microbiol.Biotechnol. Food Sci., 4, 292-296.

Chiang, J. (2014). Liver Physiology: Metabolism and Detoxification. Elsevier Inc Pathobiology of Human Disease: A Dynamic Encyclopedia of Disease Mechanism. Pathobiology of Human Disease, pp. 1770-1782

Lorke, D. (1983). A new approach to practical acute toxicity testing. Archives of Toxicology, 54(4), 275-287.

Mansfeld, R. (1986). Verzeichnis landwirtschaftlicher und gärtnerischer Kulturpflanzen. Springer, Berlin 2. Ed., pp: 1690-1691.

Olaleye, M. T., Adegboye, O. O., \& Akindahunsi, A. A. (2006). Alchornea cordifoliaextract protects wistar albino rats against acetaminophen induced liverdamage. Afr. J. Biotechnol, 5, 2439-2444.

Onwueme, I. C., Onochie, B. E., \& Sofowora, E. A. (1979). Cultivation of Thaumatococcus danielliithe sweetener. World Crops, 3, 106-111.

Osadebe, P., \& Okoye, F. B. C. (2003). Anti inflammatory effects of crude methanolic extract and fractions of Alchornea cordifolia leaves. J. Ethnopharmacol, 89, 19-24.

Ostapowicz, G., Fontana, R. J., Schiodt, F. V., Larson, A., Davron, J. T., Steven, H. B., Timothy, M., \& Reish, J. (2002). Results of a prospective study of acute liver failure at 17 tertiary care centers in the United States. Ann Intern Med., 137, 947-954.

Phrompittayarat, W., Putalun, W., Tanaka, H., Jetiyanon, K., Wittaya-areekul, S., \& Ingkaninan, K. (2007). Comparison of various extraction methods of Bacopa monnier. Naresuan University Journal, 15(1), 29-34.

Shalom, N. C., Franklyn, N. I., Boluwatife, T. M., Babajide, O. T., \& Opeyemi, C. E. (2018). Data on in vivo antioxidant, hypolipidemic and hepatoprotective potential of Thaumatococcus daniellii (Benn.) Benth leaves. Elevier, 364-370.

Tona, I., Kambu, K., Ngimbi, N., Penge, O., Lusa, K. M., Cimanga, K., De, B. T., Aperes, T. J., Pieters, I., \& Vlietinck, A. J. (2000). Anti-amoebiec and spasmolytic activities of extracts from some anti-diarrheal traditional preparations used in Kinshasha Congo. Phytomedicines, 7, 31-38.

\section{Copyrights}

Copyright for this article is retained by the author(s), with first publication rights granted to the journal.

This is an open-access article distributed under the terms and conditions of the Creative Commons Attribution license (http://creativecommons.org/licenses/by/4.0/). 